\title{
Perlukah Kesehatan Mental Remaja? Menyelisik Peranan Regulasi Emosi dan Dukungan Sosial Teman Sebaya Dalam Diri Remaja
}

\author{
Taufik Akbar Rizqi Yunanto \\ Fakultas Psikologi Universitas Surabaya, Jalan Raya Kalirungkut, Kota Surabaya, 60293 \\ e-mail: taufik_yunanto@staff.ubaya.ac.id
}

\begin{abstract}
Mental health is an important issue related to adolescent in their life. One of activitiy done by adolescent to spend their free time both at home and at school is to play with friends. In addition, friends factor becomes one of the strengthening factors in adolescent mental health. This study aims to determine the role of emotional regulation and peers social support toward mental health. This research was conducted on 102 students from Senior High School Yogyakarta, varying from 15 - 18 years old. Data was collected using teacher's role interview, teacher's role questionnaire, Mental Health Scale (Y), Emotional Regulation $\left(X_{1}\right)$ scale, and Peers Social Support $\left(X_{2}\right)$ scale. Data was analyzed using Anova and multiple regression analysis. The results showed that there was a strong relationship ( $F=66,628 ; p<0,01)$ between emotional regulation and peers social support toward mental health. Based on the analysis of determination, obtained $R^{2}$ of 0,574 or $57,4 \%$. This shows that the percentage of contributions, both independent to dependent variables is equal to 57,4\%. Further analysis is needed to find out the impact of emotional regulation and peers social support in improving mental health literacy.
\end{abstract}

Keywords: mental health, emotional regulation, peers social support

\begin{abstract}
Abstrak. Kesehatan mental merupakan masalah penting yang dihadapi oleh remaja. Salah satu kegiatan yang dilakukan oleh remaja untuk menghabiskan waktu luang mereka, baik di rumah maupun di sekolah yaitu bermain dengan teman. Selain itu, faktor teman menjadi salah satu faktor yang mempengaruhi kesehatan mental remaja. Tujuan penelitian ini untuk mengetahui peran regulasi emosi dan dukungan sosial teman sebaya dengan kesehatan mental. Responden terdiri dari 102 siswa dari Sekolah Menengah Atas Yogyakarta, yang berada dalam rentang umur 15 - 18 tahun. Pengumpulan data dilakukan dengan wawancara peran guru, kuesioner peran guru, Skala Kesehatan Mental (Y), Skala Regulasi Emosi ( $\left.\mathrm{X}_{1}\right)$, dan Skala Dukungan Sosial Teman Sebaya $\left(\mathrm{X}_{2}\right)$. Analisis data menggunakan ANOVA dan Analisis regresi linear berganda. Hasil penelitian menunjukkan bahwa terdapat hubungan yang sangat signifikan $(\mathrm{F}=66,628 ; \mathrm{p}<0,01)$ antara regulasi emosi dan dukungan sosial teman sebaya dengan kesehatan mental. Berdasarkan analisis determinasi, diperoleh $\mathrm{R}^{2}$ sebesar 0,574 atau $57,4 \%$. Analisis lebih lanjut diperlukan untuk mengetahui dampak regulasi emosi dan dukungan sosial teman sebaya dalam meningkatkan literasi kesehatan mental.
\end{abstract}

Kata kunci: kesehatan mental, regulasi emosi, dukungan sosial teman sebaya

Kesehatan mental telah menjadi isu yang hangat diperbincangkan di dunia pendidikan saat ini. Christner dan Mennuti (2009) melaporkan bahwa lebih dari 50\% remaja di sekolah menunjukkan permasalahan emosi, perilaku, dan belajar yang signifikan mempengaruhi proses pembelajarannya di sekolah, karena sekolah adalah tempat dimana remaja menghabiskan banyak waktunya. Di 
Indonesia, kesehatan mental telah menjadi bagian dari konsep sehat (UU Kesehatan No.36, 2009). Sayangnya, fokus dari program pengembangan kesehatan mental di Indonesia baru sebatas merespon bencana, seperti bencana tsunami aceh dan bom bali (Good, dkk., 2013), pembebasan pasung (Ryan, 2013), dan pelayanan jasa psikolog di puskesmas (Centre for International Mental Health, 2013). Isu mengenai kesehatan mental remaja di sekolah belum menjadi perhatian dunia pendidikan baik pada jenjang sekolah dasar maupun sekolah menengah. Adapun kondisi kesehatan mental sangat terasa pada jenjang pendidikan sekolah menengah yang identik dengan masa remaja.

Dilihat dari periode perkembangan sepanjang hayat, dinamika kesehatan mental memang sangat terlihat pada masa akil baligh atau masa pencarian identitias diri yakni pada masa remaja. Kondisi kesehatan mental remaja di Indonesia dilatarbelakangi oleh pengalamanpengalaman remaja di bidang akademik dan non akademik. Hal tersebut dikarenakan secara umum, masa remaja di Indonesia masih identik dengan masa belajar di sekolah (Monks, Knoers, \& Haditono, 2009), sehingga sebagian besar proses kehidupan remaja diwarnai oleh beragam aktivitas di bidang akademik dan non akademik.

Fakta bahwa seorang remaja pada umumnya menghabiskan sebagian waktunya di sekolah, hal tersebut berarti seorang remaja di sekolah harus melalui berbagai proses perjuangan, mulai dari memahami pelajaran yang diberikan oleh guru hingga bersosialisasi dengan teman- teman yang memiliki keanekaragaman karakteristik. Intinya, setiap remaja harus berjuang untuk mengelola emosi dan perilaku, serta dapat menangani permasalahan yang terjadi di lingkungan sekolah.

Sekolah dapat menjadi tempat yang menimbulkan rasa aman dan bahagia. Relasi yang baik dengan guru dan teman, kemampuan yang memadai untuk mengikuti pelajaran menjadikan bersekolah sebagai aktivitas yang menyenangkan. Namun, tak sedikit pula siswa yang harus berjuang untuk dapat mempertahankan keberadaannya di sekolah. Ketidakmampuan mengikuti pelajaran, kesulitan beradaptasi, tekanan dari lingkungan, pengelolaan emosi menjadi hal yang tidak mudah bagi mereka (Christner \& Mennuti, 2009).

Secara umum, kondisi tersebut menggambarkan dua sisi yang kontradiktif dari dunia persekolahan kita. Di satu sisi, sekolah dapat menjadi lingkungan yang mendukung bagi perkembangan remaja, dimana pengembangan dan aktualisasi potensi siswa dapat optimal. Namun, disisi lain sekolah dapat menjadi lingkungan yang justru menimbulkan masalah emosi dan perilaku pada anak dan remaja yang menjadi siswa.

Prestasi dalam bidang akademik dibuktikan oleh salah satu siswa yang mengalami disabilitas pada Olimpiade Sains Nasional (OSN). Siswa kelas XI dari salah satu SMA swasta di Yogyakarta berhasil menyabet medali perunggu pada Olimpiade Sains Nasional tingkat SMA-MA 2013 yang dilaksanakan di Bandung (harianjogja.com, 16 September 2016). 
Sementara dari sisi non akademik, ketercapaian kondisi kesehatan mental remaja diperlihatkan dari fakta dua siswa salah satu SMA Negeri di Yogyakarta yang mengikuti Dreamline International Design Olympiad di Ankara Turki yang diikuti oleh 18 Universitas, 57 SMA, 51 SMP dari 38 Negara yang dilaksanakan pada tanggal 13 sampai dengan 15 April 2013 dan berhasil meraih medali perak pada kompetisi tersebut

(www.pendidikan.jogjakarta.go.id/-, 22 Mei 2016).

Bertolak belakang dari prestasi gemilang diatas, kondisi kesehatan mental remaja juga mengalami kesenjangan. Beberapa fakta di Indonesia mengenai permasalahan remaja juga melingkupi berbagai permasalahan dalam aspek akademik dan non akademik juga. Berbagai tuntutan dan tantangan dari sekolah maupun lingkungan memunculkan banyak reaksi pada remaja. Mereka yang sehat mental akan mampu beradaptasi dalam menghadapi permasalahan tersebut. Sementara remaja yang tidak memiliki alternatif solusi akan memunculkan reaksi positif atas masalah tersebut.

Secara faktual peneliti melakukan survei awal pada kepolisian di daerah Yogyakarta. Dari hasil penemuan peneliti, ditemukan bahwa permasalahan yang dihadapi remaja sekolah ditunjukkan data dari Kepolisian Resort Yogyakarta (Polresta) mengenai kasus kekerasan yang melibatkan pelajar sejak tahun 2011. Pada tahun 2011, tercatat sembilan kasus dan sudah ada tiga kasus yang dilimpahkan ke kejaksaan dan enam kasus lainnya berakhir damai. Sedangkan pada tahun 2012 tercatat sebanyak lima kasus dengan dua kasus dilimpahkan ke kejaksaan sedangkan sisanya berakhir damai. Sementara itu, lima kasus kekerasan yang melibatkan pelajar sepanjang 2017 hingga Mei terjadi di lima kecamatan di Kota Yogyakarta. Ini artinya, angka kekerasan pelajar di Yogyakarta semakin meningkat. Dari awal tahun 2017 hingga Mei saja sudah tercatat 5 kasus.

Beberapa kasus tersebut didominasi oleh banyaknya pelajar SMA yang terlibat. Pada masa SMA, seorang remaja umumnya telah memasuki periode remaja tengah. Ditandai dengan perkembangan pada emotional autonomy dan remaja mulai melepaskan diri dari pengaruh keluarga. Pada periode ini, pengaruh teman sebaya menjadi lebih kuat dibandingkan dengan pengaruh dari orangtua (Story \& Stang, 2005).

Remaja mulai menginginkan adanya kebebasan dan otonomi yang oleh sebagian orangtua dianggap sebagai sebuah pemberontakan. Orangtua mulai melihat bahwa remaja mulai lepas dari kontrol mereka (Santrock, 2011). Seiring dengan meningkatnya keinginan untuk diterima dalam kelompok teman sebaya, perilakuperilaku kompromi mulai muncul (Story \& Stang, 2005).

Konformitas karena adanya tekanan dari kelompok teman sebaya dapat berdampak negatif (seperti merokok, konsumsi minuman beralkohol, penggunaan narkoba, seks bebas, dan lainlain) maupun positif. Konformitas yang bersifat positif misalnya keterlibatan dalam remaja dalam perkumpulan aktivitas sosial kemanusiaan (Santrock, 2011). 
Permasalahan kesehatan mental remaja juga dapat diakibatkan dalam ketidakmampuan memanfaatkan waktu luang dengan lebih efektif dan produktif. Krisis originalitas remaja nampak sangat jelas pada waktu luang yang dikenal dengan istilah waktu pribadi orang (remaja) itu sendiri (Monks, Knoers, \& Haditono, 2009). Remaja mengalami lebih banyak kesulitan untuk "memanfaatkan" waktu luang daripada anak-anak dan remaja lebih sering melakukan hal-hal "kill the time" dalam mengisi waktu luangnya. Oleh karena itu, para remaja sangat rentan untuk tidak menjadi produktif dan mengisi waktu luangnya dengan perilaku dan emosi negatif.

$$
\text { Kesehatan mental remaja }
$$
digambarkan seperti roller coaster pada aspek emosi dan psikologis yang kadang sangat tinggi dan kadang sangat rendah (Whitlock \& Schantz, 2008). Di sisi lain, siswa yang menghadapi permasalahan kesehatan mental akan menunjukkan perilaku negatif seperti membolos, kesulitan dalam mengerjakan tugas-tugas sekolah, dan memiliki lebih banyak konflik dengan teman sebaya atau orang yang lebih tua (Skalski \& Smith, 2006). Remaja yang berprestasi dalam bidang akademik dan non-akademik merupakan segelintir contoh remaja yang nampak sehat mental. Sedangkan kasus remaja bunuh diri, membolos, dan tawuran merupakan bentuk permasalahan kesehatan mental remaja.

Berdasarkan fakta yang terpapar oleh media, peneliti mencoba melihat tema yang paling berpengaruh dalam kehidupan sehari-hari remaja, khususnya remaja SMA melalui content analysis sebagaimana direkomendasikan Hayes (2000), atas 856 "kicauan" 21 akun twitter remaja SMA di kota Yogyakarta selama 2 minggu. Hasil preliminary study menunjukkan tema perasaan negatif (dalam hal ini regulasi emosi) dengan persentase 31,78\% dan pertemanan (dalam hal ini dukungan sosial teman sebaya) dengan persentase $25 \%$ merupakan 2 tema yang sering diperbincangkan sehari-hari oleh remaja.

Pada peringkat pertama, tema yang paling banyak dibicarakan oleh remaja SMA di kota Yogyakarta adalah perasaan negatif, dengan persentase $31,78 \%$. Tema perasaan negatif ini meliputi pembicaraan ataupun ungkapan-ungkapan mengenai keluhan sekolah, ketidakberdayaan, kebingungan, perkataan kasar (misuh), meminta perhatian, sindiran, perasaan sedih, kebingungan, dan keluhan fisik.

Selain itu, data preliminary study ini pun memperlihatkan bahwa dominasi perasaan negatif dalam kondisi remaja menunjukkan ketidaktercapaian salah satu aspek kesehatan mental yakni emotional functioning (Roeser, Eccles, dan Sameroff 1998), dimana remaja kurang mampu memahami, mengkomunikasikan, dan meregulasi emosinya (Gross \& Munoz, 1995).

Selain tema perasaan negatif, hasil preliminary study juga menemukan tema pertemanan sebagai tema dengan frekuensi terbanyak ke-2, yaitu sebesar $25 \%$. Tema ini meliputi berbagai ungkapan mengenai pertemanan, interaksi bersama, pemberian dukungan, sapaan (selamat pagi, selamat malam dan selamat ulang tahun), kangen dan permintaan maaf. Subtema pemberian 
dukungan menjadi fokus perhatian yang kerap diekspresikan dalam media twitter.

Menurut Arnett (dalam Rice \& Dolgin, 2007), pada masa remaja individu cenderung fokus untuk mendapatkan kebebasan emosional dari orangtua dan mengambil tanggung jawab dari tindakan mereka sendiri. Pada masa SMA, pengaruh teman sebaya menjadi lebih kuat dibandingkan dengan pengaruh dari orangtua (Story \& Stang, 2005). Remaja mulai menginginkan adanya kebebasan dan otonomi yang oleh sebagian orangtua dianggap sebagai sebuah pemberontakan. Orangtua mulai melihat bahwa remaja mulai lepas dari kontrol mereka (Santrock, 2011).

Persahabatan antara remaja cenderung lebih mendalam daripada umurumur sebelumnya dan melibatkan sharing permasalahan yang lebih besar. Mungkin yang menjadi alasan untuk peningkatan kedalaman hubungan tersebut, remaja (termasuk orang dewasa) memilih kawan yang memiliki kemiripan dengan dirinya (Lervolino, dkk., 2002). Pada gilirannya, hubungan antar teman sebaya memfasilitasi proses pemisahan diri dari orangtua dan membangun identitas diri sendiri sebagai seorang individu.

\section{Menurut WHO}

mengemukakan bahwa salah satu karakteristik individu yang sehat mental adalah individu yang mampu menghadapi permasalahan yang menekan dalam hidupnya. Ketidakstabilan emosi yang dihadapi oleh remaja dapat menimbulkan permasalahan pada masa remaja (Gunarsa \& Gunarsa, 2008). Fungsi emosional menjadi suatu bagian yang tak terpisahkan dari kesehatan mental. Keduanya berkaitan erat dengan kesehatan mental remaja (Roeser, Eccles, dan Sameroff, 1998).

Regulasi emosi memiliki kaitan dengan kesehatan mental. Gross dan Munoz (1995) menyatakan terdapat beberapa aspek yang mempengaruhi menurunnya kesehatan mental diantaranya adalah kesulitan dalam memahami, mengkomunikasikan dan melakukan regulasi emosi.

Penelitian Saxena, Dubey dan Pandey (2011) menemukan bahwa setiap komponen yang tercakup dalam kemampuan regulasi emosi membantu seseorang untuk mencapai kondisi kesehatan mental. Temuan dalam penelitian tersebut kemudian mengarahkan pada dugaan bahwa seseorang yang tidak memiliki pengalaman emosional yang jelas dan kurang memiliki kemampuan regulasi emosi yang cenderung lebih berisiko untuk memiliki masalah-masalah kesehatan mental dalam hidupnya.

Selain tema perasaan negatif, hasil preliminary study juga menunjukkan tema teman atau pertemanan menjadi tema yang sedang hangat di remaja SMA. Teman memainkan peran yang penting di dalam kehidupan remaja. Belle (dalam Berns, 2004) mengemukakan bahwa ketika anakanak beranjak dewasa, teman sebaya memainkan peran yang penting di dalam dukungan sosial. Teman sebaya merupakan sumber dukungan dalam bentuk afeksi, simpati, pemahaman, dan bimbingan moral.

Ketika anak-anak beranjak ke masa remaja, teman sebaya memainkan peran yang penting di dalam dukungan sosial. 
Teman sebaya merupakan sumber dukungan dalam bentuk afeksi, simpati, pemahaman, dan bimbingan moral (Berns, 2004). Dukungan sosial merupakan salah satu bentuk sumber dukungan yang berasal dari orang lain (Berns, 2004). Dukungan tersebut dapat memberikan dampak positif maupun negatif pada kesehatan mental dan kesejahteraan individu (Cohen \& Syme, 1985). Selain itu, dukungan sosial merupakan faktor protektif yang dapat membantu seseorang ketika berhadapan dengan pengalaman hidup yang menekan dan mampu menghadapinya secara efektif (Passer \& Smith, 2007).

Pentingnya peranan dukungan sosial teman sebaya bagi remaja ditegaskan oleh Shahzad, Ahmed, Jaffari, dan Khilji (2012) yang dalam penelitiannya menyatakan bahwa dukungan sosial dari teman sebaya dapat berbentuk dukungan afeksi, bimbingan, dan materi. Selain itu, Puspitasari (2010) mengemukakan bahwa dukungan sosial teman sebaya memiliki hubungan negatif terhadap kecemasan siswa yang hendak menghadapi ujian nasional (UN). Penelitian Tahmasbipour \& Taheri (2012) mengemukakan bahwa dukungan sosial berhubungan positif dengan kesehatan mental.

Dengan pemaparan mengenai kondisi dan urgensi kesehatan mental di dunia, khususnya di Indonesia yang saat ini sangat marak dalam dunia pendidikan, maka menjadi suatu hal yang mendesak bagi peneliti untuk meneliti kesehatan mental remaja di sekolah. Pemaparan diatas memunculkan suatu asumsi apakah regulasi emosi dan dukungan sosial teman sebaya memiliki peran besar terhadap kesehatan mental remaja di sekolah. Oleh karena itu, hal tersebut menjadi latarbelakang mengapa diperlukan penelitian lebih lanjut untuk dikaji secara empirik akan peran regulasi emosi dan dukungan sosial teman sebaya terhadap kesehatan mental remaja di sekolah.

\section{METODE}

\section{Responden Penelitian}

Penelitian ini merupakan penelitian kuantitatif. Lokasi penelitian adalah beberapa SMA di Yogyakarta. Penentuan SMA yang dipilih sebagai lokasi penelitian dilakukan secara purposif. Pertimbangan pemilihan lokasi penelitian adalah karena berdasarkan rekomendasi dari Kepolisian Sektor Gondokusuman yang menyatakan bahwa sekolah tersebut merupakan sekolah yang sering terlibat kasus kekerasan pelajar dan pemilihan jenjang SMA karena termasuk kategori remaja. Sebelum dilakukan pengumpulan data, maka terlebih dahulu dilakukan uji coba instrumen.

Jumlah siswa yang mengikuti uji coba skala berjumlah 94 dari 114 siswa kelas $X$. Selanjutnya untuk pengambilan data penelitian, atas rekomendasi dari pihak sekolah dan kesesuaian jadwal, peneliti mengambil data di semua kelas XI yang terdiri atas kelas XI IPA 1, XI IPA 2, XI IPS 1, XI IPS 2, XI Bahasa dengan jumlah subjek 102 siswa.

Skala yang diberikan berjumlah 102 eksemplar dan dikembalikan sesuai dengan jumlah yang dibagikan. Masing-masing subjek mengisi ketiga skala dengan baik dan benar sehingga 102 skala tersebut dapat diolah lebih lanjut. Setelah itu peneliti 
memberi skor pada jawaban yang diperoleh.

\section{Instrumen Penelitian}

Instrumen yang digunakan dalam penelitian ini ada tiga skala, yaitu skala kesehatan mental, skala regulasi emosi, dan skala dukungan sosial teman sebaya.

Skala Kesehatan Mental

Pengumpulan data kesehatan mental menggunakan Skala Kesehatan Mental. Skala ini disusun dan dikembangkan dari ciri-ciri kesehatan mental yang dikemukakan oleh Prever (2006). Peneliti menyusun 50 aitem pernyataan yang mengungkap seluruh ciriciri kesehatan mental. Subjek diminta untuk memberikan respon terhadap pernyataanpernyataan tersebut.

Setelah skala kesehatan mental diuji cobakan dan dianalisis melalui seleksi aitem, didapat hasil 46 butir sahih dan 4 aitem gugur dengan menghasilkan reliabilitas skala kesehatan mental menghasilkan nilai koefisien Alpha sebesar 0,881 dengan koefisien korelasi aitem total bergerak dari 0,251 sampai 0,547.

Skala Regulasi Emosi

Pengumpulan data regulasi emosi menggunakan Skala Regulasi Emosi yang disusun oleh peneliti. Skala ini disusun dan dikembangkan dari aspek-aspek regulasi emosi yang dikemukakan oleh Gross \& Thompson (2007). Hasil analisis uji reliabilitas skala regulasi emosi menghasilkan nilai koefisien Alpha sebesar 0,733 sehingga skala ini dianggap reliabel. Hasil analisis aitem terhadap 20 aitem pernyataan pada 94 subjek uji coba menghasilkan 18 aitem yang dapat diterima, sedangkan 2 aitem dinyatakan gugur dengan korelasi aitem total yang bergerak dari 0,227 sampai 0,479. Aitem hasil uji coba, sebelum digunakan dalam penelitian yang sebenarnya diatur kembali nomor-nomor aitemnya.

Skala Dukungan Sosial Teman Sebaya

Pengumpulan data dukungan sosial teman sebaya menggunakan Skala Dukungan Sosial Teman Sebaya yang disusun oleh peneliti. Skala ini disusun dan dikembangkan dari aspek-aspek dukungan sosial teman sebaya yang dikemukakan oleh House (dalam Smet, 1994). Hasil analisis uji reliabilitas skala dukungan sosial teman sebaya menghasilkan nilai koefisien Alpha sebesar 0,944 sehingga skala ini dianggap reliabel. Hasil analisis aitem terhadap 40 aitem pernyataan pada 94 subjek uji coba menghasilkan 34 aitem yang dapat diterima, sedangkan 6 aitem dinyatakan gugur dengan korelasi aitem total yang bergerak dari 0,398 sampai 0,818. Aitem hasil uji coba, sebelum digunakan dalam penelitian yang sebenarnya diatur kembali nomor-nomor aitemnya.

\section{Prosedur Pelaksanaan Penelitian}

Peneliti meminta bantuan para siswa untuk mengisi skala-skala yang dibawa peneliti. Peneliti lalu membagikan 1 bendel yang berisi Skala Kesehatan Mental, Skala Regulasi Emosi, dan Skala Dukungan Sosial Teman Sebaya. Peneliti juga memberikan contoh singkat cara mengisinya. Para siswa kemudian dipersilakan untuk mulai mengisi skala setelah mereka memahami cara mengisinya. Setelah selesai mengisi, peneliti kemudian memberikan reward. 


\section{Analisis Data Penelitian}

Hipotesis penelitian yang diajukan dalam penelitian ini akan diuji dengan menggunakan metode statistik. Metode analisis data yang digunakan untuk menguji hipotesis penelitian tersebut adalah teknik regresi linear berganda. Analisis ini digunakan untuk mengetahui arah hubungan antara variabel independen, apakah berhubungan positif atau negatif, terhadap variabel dependen (Priyatno, 2008). Dalam hal penelitian ini, terdapat dua variabel independen, yaitu variabel Regulasi Emosi $\left(X_{1}\right)$ dan variabel Dukungan Sosial Teman Sebaya $\left(\mathrm{X}_{2}\right)$.

\section{HASIL}

Berdasarkan hasil analisis diperoleh angka korelasi ganda $\mathrm{R}=0,757$. Hal ini menunjukkan bahwa terjadi hubungan yang kuat antara variabel $X_{1}$ dan $X_{2}$ terhadap variabel dependen. Koefisien determinasi yang digunakan untuk mengetahui seberapa besar kemampuan variabel regulasi emosi dan dukungan sosial teman sebaya menjelaskan variabel kesehatan mental ditunjukkan oleh nilai $\mathrm{R}^{2}$ sebesar 0,574. Angka tersebut mengandung pengertian bahwa dalam penelitian ini, regulasi emosi dan dukungan sosial teman sebaya memberikan sumbangan efektif sebesar 57,4\% terhadap kesehatan mental. Hal ini berarti masih terdapat $42,6 \%$ faktor lain yang mempengaruhi kesehatan mental.

Selain dengan analisis korelasi ganda, peneliti juga menguji hipotesis dengan koefisien regresi secara bersamasama (Uji F). Uji ini dilakukan untuk mengetahui apakah variabel independen secara bersama-sama berpengaruh secara signifikan terhadap variabel dependen. $\mathrm{F}$ hitung $=66,628$. Uji $\mathrm{F}$ dilakukan dengan membandingkan $\mathrm{F}$ hitung dengan $\mathrm{F}$ tabel. Jika $\mathrm{F}$ hitung $>\mathrm{F}$ tabel maka terdapat hubungan secara signifikan antara variabel $X_{1}$ dan $X_{2}$ secara bersama-sama terhadap variabel dependen. Dengan menggunakan taraf signifikansi 5\%, df 1 (Jumlah variabel $1)=2, d f 2(n-k)=99(n$ adalah jumlah data dan $\mathrm{k}$ adalah jumlah variabel independen), diperoleh $\mathrm{F}$ tabel $=3,09$. Dengan demikian, karena F hitung > F tabel $(66,628>3,09)$, maka dapat dinyatakan bahwa terdapat hubungan yang signifikan antara Regulasi Emosi dan Dukungan Sosial Teman Sebaya dengan Kesehatan Mental secara bersamasama. Hal ini berarti model regresi dapat dipakai untuk memprediksi kesehatan mental.

Dari hasil analisis-analisis diatas, hipotesis yang menyatakan terdapat hubungan antara regulasi emosi dan dukungan sosial teman sebaya dengan kesehatan mental remaja dapat diterima.

\section{DISKUSI}

Berdasarkan hasil analisis, dinyatakan bahwa $\mathrm{F}=66,628 ; \mathrm{p}<0,01$ sehingga hipotesis dapat diterima. Dengan kata lain, regulasi emosi dan dukungan sosial teman sebaya memiliki hubungan positif dengan kesehatan mental remaja. Artinya, semakin baik regulasi emosi dan semakin besar dukungan sosial yang diterima dari teman-teman sebayanya, maka kesehatan mental remaja tersebut akan semakin tinggi. Hal ini sejalan dengan apa yang dikemukakan WHO (2005) tentang faktor risiko dan faktor protektif bahwa dari sudut pandang psikologis, 
faktor risiko yang mempengaruhi kesehatan mental adalah masalah emosional dan dari sudut pandang sosial adalah dukungan dari lingkungan sekitar salah satunya dukungan sosial dari lingkungan sekitar mereka (dalam hal ini teman sebayanya. Dari hal tersebut, faktor protektif tentang kemampuan untuk regulasi emosi dan dukungan dari teman sebayanya di sekolah akan membuat mereka merasa nyaman berada di sekolah tersebut dan menciptakan lingkungan yang kondusif.

Seperti yang telah ditulis dalam tinjauan pustaka, bahwa kemampuan regulasi emosi secara signifikan memberikan sumbangan positif bagi kesehatan mental seseorang. Saxena, Dubey dan Pandey (2011) menemukan bahwa setiap komponen yang tercakup dalam kemampuan regulasi emosi membantu seseorang untuk mencapai kondisi kesehatan mental. Sejalan juga dengan yang diungkapkan oleh Coleman \& Vaughn (dalam Kumara, 2012) yang mengatakan bahwa para pelajar yang mengalami kesukaran perilaku dan emosi di sekolah sering mengalami kegagalan akademik dan sejumlah interaksi sosial yang negatif. Dari 11 ciri remaja sehat mental yang dikemukakan oleh Prever (2006), penelitian ini dikhususkan untuk menjelaskan tentang peran kemampuan regulasi emosi dan dukungan sosial dari teman sebayanya. Seperti halnya yang dikemukakan Moos (2002) tentang framework kesehatan mental remaja bahwa regulasi emosi termasuk dalam personal system dan dukungan sosial teman sebaya masuk dalam environmental system yang mana kedua hal tersebut memiliki peran dengan kesehatan mental.

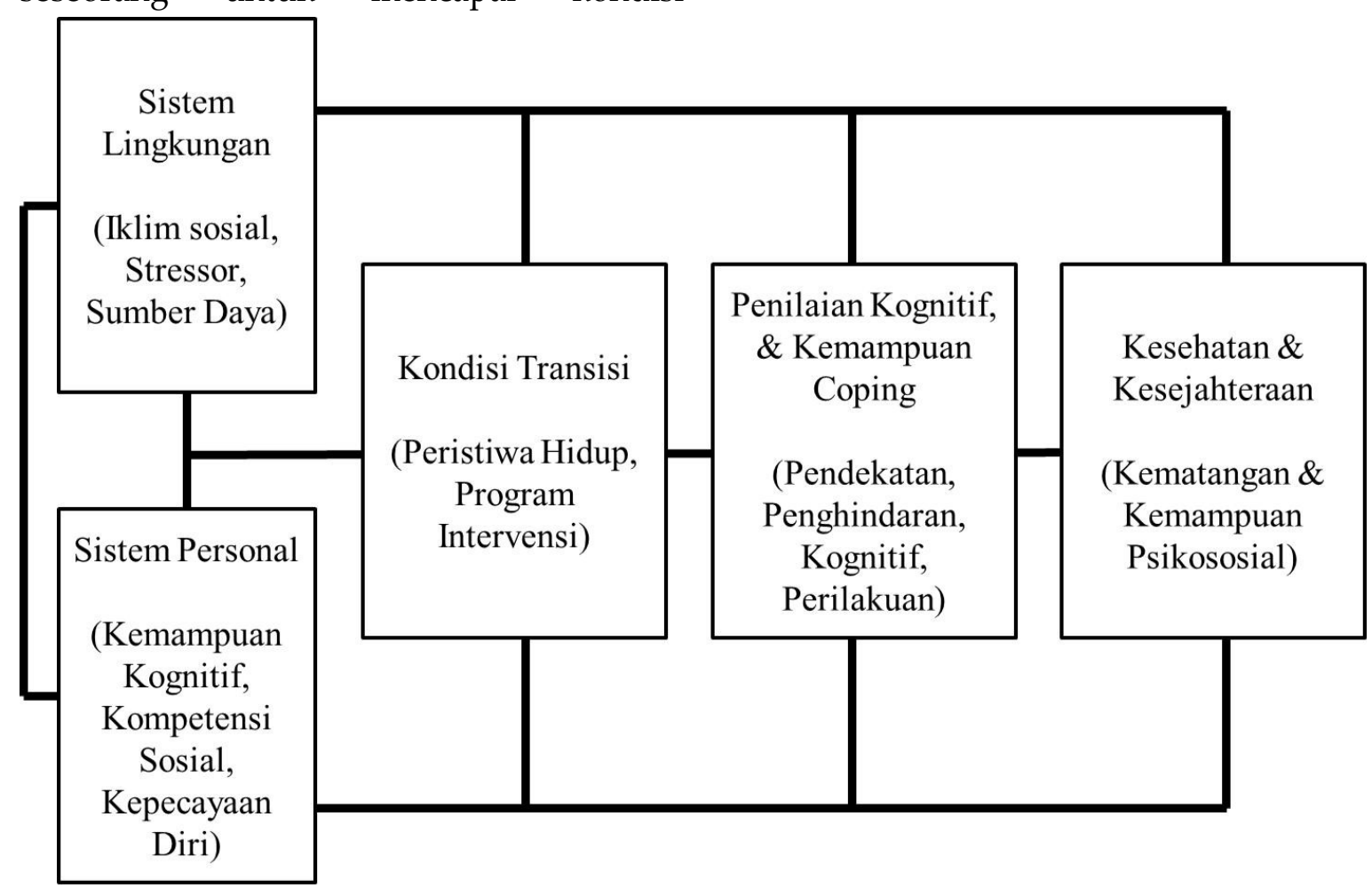

Gambar 1. Bagan Kesehatan Mental Remaja Dikembangkan dari Penelitian Moos (2002) 
Pada penelitian ini didapat bahwa kategori kesehatan mental subjek terdapat pada kategori sedang dan tinggi, dan tidak ditemukan subjek yang berada pada kategori rendah. Hal ini juga dapat dilihat dari mean empirik kesehatan mental sebesar 173, 23 berada dalam kategori tinggi. Berdasar kategorisasi, sebesar 61,77\% sejumlah 63 subjek berada pada kategori tinggi, sedangkan 39 subjek atau 38,23\% dari subjek penelitian berada pada kategori sedang, dan tidak ada subjek $(0 \%)$ yang berada pada kategori rendah. Pada penelitian ini didapat bahwa kategori regulasi emosi subjek terdapat pada kategori sedang dan tinggi, dan tidak ditemukan subjek yang berada pada kategori rendah.

Hal ini juga dapat dilihat dari mean empirik skala regulasi emosi sebesar 65,75 termasuk kategori tinggi yang berarti pula bahwa skor subjek rata-rata termasuk dalam kategori tinggi. Sebanyak 54,91\% atau sejumlah 56 orang berada dalam kategori tinggi, 45,9\% subjek atau sejumlah 46 orang berada dalam kategori sedang, dan tidak ada subjek ( $0 \%)$ yang berada pada kategori rendah. Hal serupa juga terjadi dalam kategorisasi dukungan sosial teman sebaya. Mean empirik skala dukungan sosial teman sebaya sebesar 133,66 termasuk kategori tinggi. Sebanyak $70,59 \%$ atau sejumlah 72 orang berada dalam kategori tinggi, 29,41\% subjek atau sejumlah 30 orang berada dalam kategori sedang, dan tidak ada subjek $(0 \%)$ yang berada pada kategori rendah.

Berdasarkan hasil kategorisasi tersebut terlihat bahwa remaja SMA di Yogyakarta menunjukkan kondisi yang dapat dibilang positif. Data dari Kepolisian menyebutkan bahwa SMA tersebut sering terlibat kasus kekerasan antar pelajar, seperti tawuran, pembacokan, dan sebagainya. Hal ini menunjukkan bahwa atribut negatif yang selama ini diberikan kepada sekolah tersebut tidak terbukti seutuhnya. Siswa yang termasuk dalam kategori sedang, mungkin masih mengalami kebingungan dalam memilih kegiatan yang menunjang dirinya, sehingga ketika siswa yang berada dalam kondisi ini rawan untuk mendapatkan pengaruh dari teman sebayanya. Dari hal tersebut dapat jadi kasus yang dimaksudkan oleh Kepolisian adalah siswa-siswa yang berada dalam kategori sedang ini.

Menurut Santrock (2011) bahwa teman sebaya memiliki peran lingkungan terdekat memiliki peran yang besar dalam diri seorang remaja, karena pada masa ini peran orangtua/keluarga sudah mulai berkurang. Sebaliknya, siswa yang termasuk dalam kategori tinggi merupakan siswa yang sudah mampu mengelola emosinya secara efektif dan mendapatkan dukungan sosial dari teman sebaya yang positif sehingga kesehatan mental nya juga baik. Hal ini menunjukkan siswa yang termasuk dalam kategori tinggi sudah mampu untuk menangani masalah yang dihadapinya, sehingga mereka lebih terlibat dalam aktivitas-aktivitas yang positif, sehingga dalam hal ini permasalahan seputar kesehatan mental, regulasi emosi, dan dukungan sosila teman sebaya dapat teratasi.

Kesehatan mental dalam hal ini diartikan sebagai performa sukses dari seseorang yang dapat menghasilkan aktivitas produktif, menjalin hubungan dengan orang lain, beradaptasi dengan 
perubahan, dan mengatasi perbedaan (Surgeon's General, dalam Prever., 2006) tidak dapat dipahami sebagai satu hal yang statis atau linier (Moos, 2002). Apalagi ketika kita membahas kesehatan mental dalam konteks siswa SMA yang masuk dalam kategori remaja yang senantiasa disertai dengan kompleksitas masa transisi kehidupan \& perkembangan (Santrock, 2011). Meskipun kesehatan mental seolah bersifat sangat personal terkait kualitas kehidupan, namun berbagai perubahan di sekitar remaja membuat konteks kesehatan mental remaja menjadi satu hal yang luas (Moos, 2002).

Dalam tinjauan pustaka disebutkan bahwa emosi perlu dikelola sedemikian rupa agar dapat berfungsi secara lebih adaptif dan positif dalam diri seseorang (Gross, 1998). Adapun individu yang mampu mengelola emosi dapat diartikan sebagai individu yang telah belajar untuk mampu mengekspresikan perasaan secara efektif, melibatkan keseimbangan antara ekspresi spontan dengan yang disadari serta menggunakan kontrol rasional (Atwater \& Duffy, 2005). Dalam studi preliminary peneliti memperlihatkan adanya bentuk pengekspresian emosi dalam media sosial yang sifatnya ekspresif informatif. Kondisi ini memperlihatkan bahwa remaja merefleksikan kondisi psikologis terkait kondisi emosional yang dialaminya sebagai bentuk informasi kepada orang-orang disekitarnya. Merujuk pada kerangka Moos (2002), fungsi emosional yang termuat dalam sistem personal remaja menjadi suatu bagian yang tak terpisahkan dari kesehatan mental. Keduanya berkaitan erat dengan kesehatan mental remaja (Roeser, Eccles, dan Sameroff 1998).

Regulasi emosi yang berada dalam sistem personal remaja dapat mempengaruhi kondisi kesehatan mental remaja. Hasil kategorisasi menunjukkan bahwa regulasi emosi remaja dalam penelitian termasuk positif. Artinya, kemampuan regulasi emosi menjadi hal yang penting dalam kehidupan seorang remaja. Faktor emosional pada remaja berperan dalam kesehatan mental. Individu yang mengelola emosi dapat diartikan individu tersebut belajar untuk dapat mengekspresikan perasaan secara efektif, melibatkan keseimbangan antara ekspresi spontan dengan yang disadari serta menggunakan kontrol rasional (Atwater \& Duffy, 2005). Hal ini sejalan dengan apa yang dikemukakan oleh Gross dan Munoz (1995), terdapat beberapa aspek yang mempengaruhi kesehatan mental diantaranya adalah memahami, mengkomunikasikan dan melakukan regulasi emosi.

Moos (2002) yang memberikan gambaran mengenai environmental system atau aspek eskternal salah satunya terdiri dari social climate yang termasuk didalamnya berupa dukungan sosial. Individu yang mendapatkan dukungan sosial percaya bahwa individu tersebut dicintai dan diperhatikan, mulia dan dihargai, dan merupakan bagian dari jaringan sosial, misalnya keluarga atau organisasi kemasyarakatan. Individu tidak merasa sendiri dan cepat putus asa dalam menghadapi permasalahan yang dihadapinya karena ada orang-orang disekelilingnya yang membantu dan 
memberi dukungan. Beberapa penelitian menemukan bahwa faktor dukungan sosial sebagai suatu sistem lingkungan mempengaruhi kesehatan mental remaja di sekolah.

Dengan demikian, teman sebaya memiliki peran yang penting dan juga sentral dalam menyediakan bentuk-bentuk dukungan biasa/umum yang langsung dan dapat diakses dan menunjukkan konsistensi signifikansi dalam mempromosikan kesehatan mental remaja. Hasil penelitian yang dilakukan McGrath, dkk. (2009) mengkonfirmasikan bahwa teman merupakan sumber penting yang menyediakan dukungan emosional. Dukungan emosional merupakan bentuk dukungan yang lebih sensitif dan berhubungan dengan perasaan dan biasanya melibatkan hubungan yang dekat (hubungan karib).

Biasanya hal ini menyangkut hal-hal seperti, selalu ada untuk orang yang dekat, mendengarkan mereka ketika mereka sedang sedih, dan memberikan dukungan yang tanpa syarat. Adapun penelitian lain yang dilakukan oleh Tahmasbipour \& Taheri (2012) mengatakan bahwa dukungan sosial berhubungan positif dengan kesehatan mental mahasiswa di Shahid Rajaee University di Iran. Penelitian tersebut mengatakan bahwa semakin tinggi dukungan sosial akan diikuti dengan meningkatnya kesehatan mental. Hal tersebut senada dengan apa yang diungkapkan oleh Santrock (2011) bahwa teman sebaya memiliki peran yang penting selama masa remaja karena anak sudah mulai meluangkan waktu bersama dengan teman-teman sebaya. Pengelolaan emosi dan interaksinya dengan teman sebaya memiliki peran terhadap kondisi kesehatan psikis remaja.

$$
\text { Berdasarkan hasil analisis }
$$

determinasi, diperoleh $\mathrm{R}^{2}$ sebesar 0,574 atau $57,4 \%$. Hal ini menunjukkan bahwa persentase sumbangan efektif kedua variabel independen terhadap variabel dependen adalah sebesar 57,4\%. Artinya, variasi variabel regulasi emosi dan dukungan sosial teman sebaya mampu menjelaskan sebesar $57,4 \%$ variasi variabel kesehatan mental. Sedangkan sisanya 42,6\% dipengaruhi oleh variabel lain yang tidak dimasukkan dalam penelitian ini.

Oleh karena itu, dengan berbagai kompleksitas permasalahan yang meliputi kesehatan mental remaja di sekolah, berdasarkan apa yang disampaikan Moos (2002) dan Christner \& Mennuti (2009) masih dibutuhkan proses jangka panjang, komprehensif, dan sinergis untuk mewujudkan terciptanya kualitas kesehatan mental remaja di sekolah. Dalam konteks sekolah, kesehatan mental berbasis sekolah merupakan faktor penting dalam mewujudkan kesehatan emosional siswa, kemampuan belajar yang optimal, dan kesediaan seorang siswa untuk menempuh pendidikan (Christner \& Mennuti, 2009). Kualitas kesehatan mental ini merupakan cerminan sekaligus modalitas penting bagi seorang remaja untuk melewati masa-masa sekolahnya yang penuh dengan tantangan eksternal maupun dinamika personalnya. 


\section{KEPUSTAKAAN}

Atwater, E \& Duffy, K. G. (2005). Psychology for Living: Adjusment, Growth and Behaviour Today (8th Edition). New Jersey: Pearson Prentice.

Berns, R.M. (2004). 6 $6^{\text {th }}$ Edition: Child, Family, School, Community: Socialization and Support. California: ThomsonWadsworth.

Christner, R.W. \& Mennuti, R.B. (2009). School-Based Mental Health. New York: Routledge.

Cohen, S. \& Syme, S.L. (1985). Social Support and Health. San Fransisco: Academic Press.

Coleman, M., \& Vaughn, S. (2000). Reading interventions for students with emotional/behavioral disorders. New York: Columbia University TeenScreen Program.

Gross, J.J. \& Munoz, R.F. (1995). Emotion Regulation and Mental Health. American Psychological Association D12. http://spl.stanford.edu/pdfs/1995\%20 Clinical\%20Psychology\%20Science $\% 2$ 0and $\% 20$ Practice $\% 20$ -

\%20Emo.\%20Reg.\%20and\%20Mental $\% 20$ Health.pdf tanggal 30 Agustus 2017.

Gross, J. J. \& Thompson, R. A. (2007). Emotion regulation: Conceptual foundations.In J. J. Gross (Ed.), Handbook of emotion regulation. New York: Guilford Press

Gunarsa, S.D. \& Gunarsa, Y.S. (1983). Psikologi Perkembangan Anak dan Remaja. Jakarta: PT. BPK Gunung Mulia.

Hayes, J. R. (2000). A New Framework for Understanding Cognition and. Perspectives on writing: Research, theory, and practice, 6.

Kumara, A. (2012). Permasalahan Kesehatan Mental Remaja di DIY. (Laporan Penelitian tidak dipublikasikan).
Fakultas Psikologi Universitas Gadjah Mada, Yogyakarta.

Lervolino, A. C., Pike, A., Manke, B., Reiss, D., Hetherington, E. M., \& Plomin, R. (2002). Genetic and environmental influences in adolescent peer socialization: Evidence from two genetically sensitive designs. Child development, 73(1), 162-174.

McGrath, B., Brennan, M. A. Dolan, P., \& Barnett, R. (2009). Adolescent wellbeing and supporting contexts : A comparison of adolescents in Ireland and Florida. Journal of Community and Applied Social Psychology, 19, 299-320.

Mental Health Foundation (MHF). (2001). http://www.mentalhealth.org.uk/help -information/an-introduction-tomental-health/what-is-mental-health/ tanggal 5 September 2017.

Monks, F.J., Knoers, A.M.P., Haditono, S.R. (2009). Psikologi Perkembangan: Pengantar dalam Berbagai Bagiannya. Yogyakarta: Gadjah Mada University Press.

Moos, R. H. (2002). Life Stressors, Social Resources, and Coping Skills in Youth: Applications to Adolescents With Chronic Disorders. Journal of Adolescent Health, 30 (4), 22-29.

Passer, M. \& Smith, R. (2007) Psychology; The science of mind and behavior. New York: McGraw-Hill.

Prever, M. (2006). Mental Health in Schools. London: Paul Chapman Publishing.

Priyatno, D. (2008). Mandiri belajar SPSS. Jakarta: Mediakom.

Puspitasari, Y.P., Abidin, Z., Sawitri, D.R. (2010). Hubungan antara Dukungan Sosial Teman Sebaya terhadap Kecemasan Menjelang Ujian Nasional (UN) pada Siswa Kelas XII Reguler SMA Negeri 1 Surakarta. SKRIPSI. http://eprints.undip.ac.id/24776/ tanggal 20 Juli 2017 
Rice, F. P., \& Dolgin, K. G. (2002). The Adolescent Development, Relationships, and Culture. Boston: Allyn \& Bacon.

Roeser, R.W., Eccles, J.S., Sameroff, A.J. (1998). Academic and emotional functioning in early adolescence: Longitudinal relations, patterns, and prediction by experience in middle school. Development and Psychopathology, 10, 321-352.

Santrock, J.W. (2011). Life-Span Development:13 th Edition. New York: McGraw-Hill.

Saxena, P., Dubey, A., \& Pandey, R. (2011). Role of Emotion Regulation Difficulties in Predicting Mental Health and Well-being. SIS J. Proj. Psy. E Mental Health 18: 147-155.

Shahzad, A., Ahmed, T., Jaffari, S.I.A., Khilji, B.A. (2012). Impact Of Self Esteem \& Support On Student Performance. Journal Management $\mathcal{E}$ Marketing, Vol. 10, Issue 2, pp. 352-358.

Skalski, A. K. \& Smith, M.J. (2006). Responding to the mental health needs of students. Principal Leadership, $12-15$.
Smet, B. (1994). Psikologi Kesehatan. Jakarta : PT Gramedia Widiasarna Indonesia

Story, M. \& Stang, J. (2005) Nutrition needs of adolescents. In: Stang, J. and Story, M., Eds., Guidelines for Adolescent Nutrition Services, University of Minnesota, Minneapolis, 21-34.

Tahmasbipour, N. \& Taheri, A. A. (2012). Survey on the relation between social support and mental health in students Shahid Rajaee University. ELSEVIER Procedia - Social and Behavioral Sciences 2012 Vol: 47, Hal: 5-9.

Thompson, R. A., \& Meyer, S. (2007). Socialization of Emotion Regulation in the Family. In J. J. Gross, Handbook of Emotion Regulation (pp. 249-269). New York: Guilford Press.

Whitlock, J. \& Schantz, K. (2008). Mental Illness and Mental Health. ACT for Youth Center of Excellence: Research Facts and Findings.

World Health Organization (WHO). (2011). http://www.who.int/features/qa/62/e n/ tanggal 17 Juni 2017. 